\title{
Author Correction: Temporal changes in global soil respiration since 1987
}

\author{
Jiesi Lei, Xue Guo (1), Yufei Zeng, Jizhong Zhou (1), Qun Gao (1) \& Yunfeng Yang (1)
}

Correction to: Nature Communications https://doi.org/10.1038/s41467-020-20616-z, published online 15 January 2021.

The original version of this Article contained errors in Figure 1 and Figure 3 axes labels. In the y-axis of Figure $1 \mathrm{~d}, \Delta R_{\mathrm{s}}$ should read $R_{\mathrm{s}}$; in the y-axis of Figure $3 \mathrm{~d} R_{\mathrm{s}}$ should read $R_{\mathrm{h}}$; in the y-axis of Figure $3 \mathrm{e} R_{\mathrm{s}}$ should read $R_{\mathrm{a}}$. This has been corrected in both the PDF and HTML versions of the Article.

Published online: 16 March 2021

\footnotetext{
(c) (i) Open Access This article is licensed under a Creative Commons Attribution 4.0 International License, which permits use, sharing, adaptation, distribution and reproduction in any medium or format, as long as you give appropriate credit to the original author(s) and the source, provide a link to the Creative Commons license, and indicate if changes were made. The images or other third party material in this article are included in the article's Creative Commons license, unless indicated otherwise in a credit line to the material. If material is not included in the article's Creative Commons license and your intended use is not permitted by statutory regulation or exceeds the permitted use, you will need to obtain permission directly from the copyright holder. To view a copy of this license, visit http://creativecommons.org/licenses/by/4.0/.
}

(C) The Author(s) 2021 